\title{
PERFORMANCE ANALYSIS OF ACTIVE-CLAMPED INTERLEAVED FLY-BACK INVERTER FOR PHOTOVOLTAIC APPLICATIONS
}

\author{
C.Kirthana ${ }^{1}$, R.Deepa ${ }^{2}$, M.SasiKumar ${ }^{3}$ \\ ${ }^{1,2}$ PG Scholar, Department of Power Electronics \& Drives, Jeppiaar Engineering College, Chennai \\ ${ }^{3}$ Professor and Head, Department of Electrical and Electronics \&Drives, Jeppiaar Engineering College, Chennai \\ kirthi46@gmail.com,deepa.red7@gmail.com,pmsasi77@gmail.com
}

\begin{abstract}
A new control strategy has been proposed for the interleaved flyback inverter. the proposed method consists of two control strategies, they are active clamp control and phase control. Based on the output power of the PV module each converter phase of an ILFI is controlled. due to the active clamp control method the energy in the leakage inductance can be fully recycled. the concept of interleaving reduces the ripple and reduces the usage of capacitors. The induction motor drive has been used the speed performance of the drive has been analyzed simulations are done using MATLAB. The parameters are analyzed without PV and with PV. The explanations, theories and results are discussed further.
\end{abstract}

Keywords- interleaved flyback inverter, active clamp, photovoltaic, induction motor drive

\section{INTRODUCTION}

Nowadays the standby power loss and efficiency of the power supply are of major concern the average efficiency instead of full load efficiency is important for external power supplies such as adaptors. the challenge for the power supply design is created by the light load and full load efficiency. for offline applications flyback converters are used generally due to its simplicity and low cost.to dissipate the leakage energy when the switch is off an RCD clamp circuit is used. To minimize the voltage spikes across the switch becomes difficult with the presence of well coupled transformer with minimized leakage inductance.this results in usage of a labor intensive manufacturing process. by reducing the leakage inductance energy loss the efficiency can be improved. The concept of interleaving enables these converter topologies to operate at increased power levels. The benefits of interleaving include $\square$ Reduced RMS current in the input capacitors enabling the use of less expensive and fewer input capacitors $\square$ Ripple current cancellation in the output capacitor, enabling the use of less expensive and fewer output capacitors $\square$ Reduction of peak currents in primary and secondary transformer windings. $\square$ Improved transient response as a result of reducing output filter inductance and higher output ripple frequency Separation of heat generating components allowing for reduced heat sink requirements . $\square$ Improved form factor for low profile solutions Reduced EMI as a result of reduced peak currents $(2 \mathrm{~L}$ interleaved forward converter.

\section{ILFI STRUCTURE \& MODES OF OPERATION}

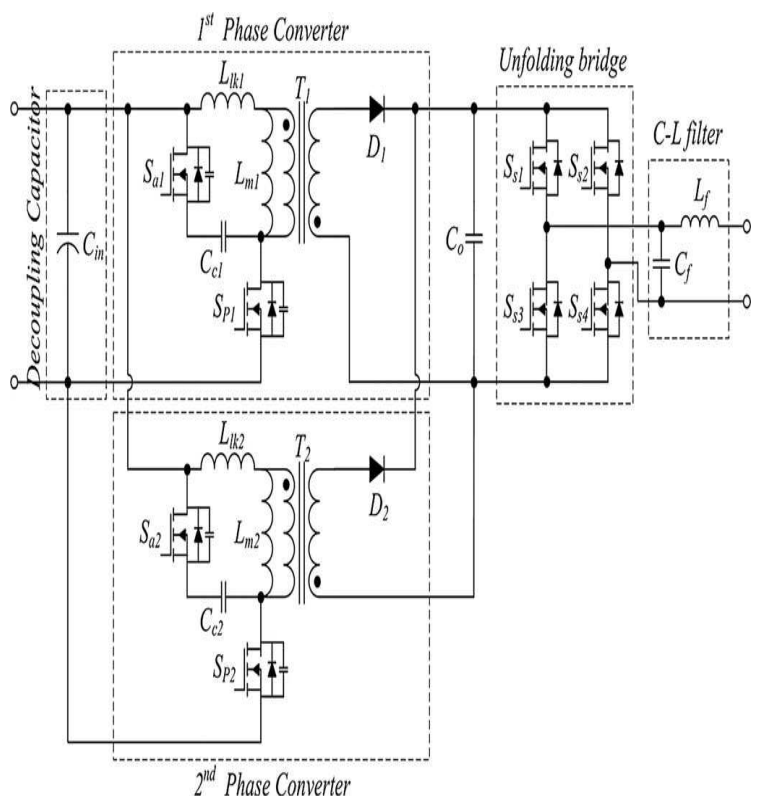

Fig. 1 ILFI structure

The ILFI is designed for a PV AC module system. A decoupling capacitor, first phase converter, second phase converter, unfolding bridge, and $\mathrm{C}$-L filter are present in the proposed inverter. The maximum power point tracking is essential for the generation of peak power in the PV AC module system. constant PV voltage and PV current are required for 
MPPT control. the $120 \mathrm{HZ}$ harmonic frequency which distorts the PV voltage and PV current are removed by the decoupling capacitor. there are main switches, diodes, transformers, in each phase. The voltage spikes across the main switch is reduced by the clamp circuit. the isolation between the PV module and the grid line is produced by the transformer .it also boosts the voltage. the connection between the AC power produced by the transformer and grid line is employed by the unfolding bridge. The steady state operating stages are given below.

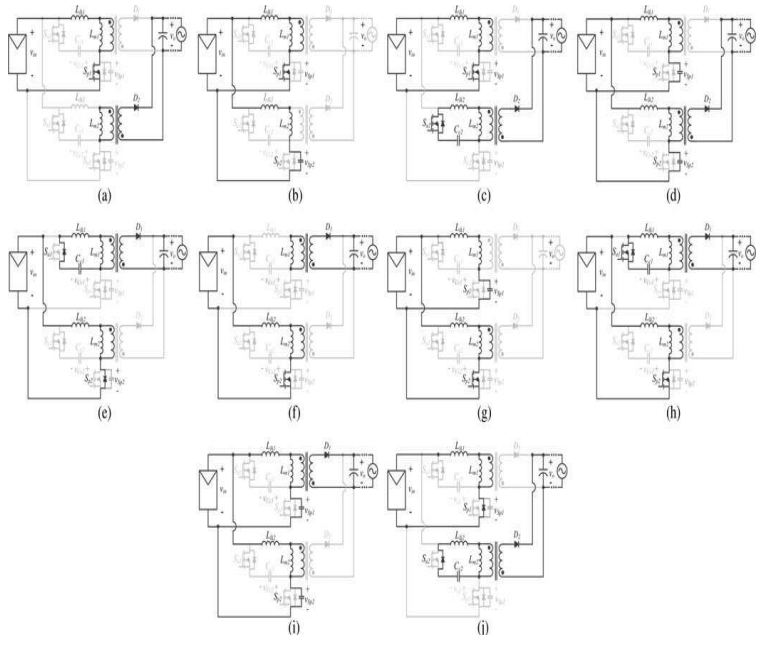

Fig. 2 Equivalent circuits in steady-state operation

(a) Mode 1 [t0 - t1 ]. (b) Mode 2 [t1 - t2 ]. (c) Mode 3 [t2-t3 ]. (d) Mode 4 [t3 - t4 ]. (e) Mode 5 [t4-t5 ].

(f) Mode $6[\mathrm{t} 5-\mathrm{t} 6]$. (g) Mode $7[\mathrm{t} 6-\mathrm{t} 7]$. (h) Mode 8 [t7 - t8 ]. (i) Mode 9 [t8-t9 ]. (j) Mode $10[\mathrm{t} 9-\mathrm{t} 10]$.

Due to the simplicity of control the discontinuous mode is considered.the main switches are provided with two gate signals of 180degree phase shift.sp1 and sp2 are the main switches.sa1 sa2 are the active clamp switches.the gate signals of the clamp switches are applied for short time to reduce the conduction loss of the switches. The ILFI activates a singlephase converter without the active clamp circuit using the phase control method and the active clamp control method because the output power of the PV module is higher than half of the PV module maximum power and the voltage spike across main switch Sp1 is smaller than the Sp1 voltage rating. Therefore, the second-phase converter loss and clamp circuit loss can be removed. In Fig. 3(b), the ILFI activates a single-phase converter with the active clamp circuit using the phase control method because the output power of the PV module is smaller than half of the PV module maximum power and the voltage spike across the $\mathrm{Sp} 1$ is larger than the $\mathrm{Sp} 1$ voltage rating. Therefore, the second-phase converter loss can be eliminated. When the output power of the PV module is larger than half of $\mathrm{PV}$ module maximum power and the voltage spikes across main switch $\mathrm{Sp} 1$, and $\mathrm{Sp} 2$ is larger than the $\mathrm{Sp} 1$, and $\mathrm{Sp} 2$ voltage rating, the ILFI is fully activated as represented.

\section{ACTIVE CLAMP CONTROL METHOD}

Solar irradiance and atmospheric temperature influence the output power of the PV module. based on the irradiance values of the weather conditions the efficiency of the ILFI has to be improved. the active clamp circuit reduces the voltage spikes across the main switch. ILFI is made of two phases. The losses are reduced by controlling each phase of the ILFI the sp1 voltage without the clamp circuit. the sum of input voltage vin through the PV module, the feedback voltage, spike voltagevsp1 forms the voltage across $\mathrm{sp} 1$ when $\mathrm{sp} 1$ is turned off.sp1 is failed when the vsp1 is above the switch rating voltage VRT .thus active clamp circuits have been used in flyback inverter for reducing voltage across main switch. the waveform of the main switch when the clamp circuit is used.clamp capacitor $\mathrm{Cc} 1$ absorbs the energy in the Llk1 of the transformer.this reduces the voltage spike across the main switch.thus a new active clamp control has been used to reduce the conduction loss ,switching loss of the clamp circuit.

\section{MODELLING OF PV ARRAY}

The only way to generate power from sun is done by usage of photovoltaic cells. besides being efficient they are convenient to use. silicon is the material used for manufacturing of PV cells. solar cell preparation should be in a very clean environment. In this technology the energy from sun is transformed into direct current electricity.maximum power point is a unique operating point supplying maximum power to the load which is present in a PV array. tracking the maximum power point of the PV array is done to improve the efficiency of the photovoltaic energy system MPPT is an electronic system that operates the Photovoltaic (PV) modules in a manner that allows the modules to produce all the power capable of PV module MPPT is not a mechanical tracking system that "physically moves" the modules to make them point more directly at the sun. MPPT is a fully electronic system that varies the electrical operating point of the modules, so that the modules are able to deliver maximum available power. Additional power harvested from the modules is then made available as increased battery charge current.

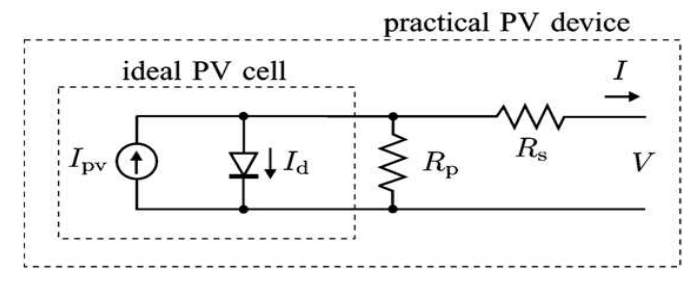

Fig 4 equilant circuit 


\section{CURRENT CONDUCTION IN SOLAR CELL}

An ultra thin layer of phosphorus-doped ( $\mathrm{N}$ type) silicon on top of (P type ) silicon form a PV cell. when these two materials are in contact an electrical field is created called $\mathrm{P}-\mathrm{N}$ junction .a momentum and direction is provided by this electrical field when sun light strikes the surface of a pv cell. thus when the solar cell is connected to the electrical field current flow takes place. area of the cell,atmospheric conditions determine the current from a PV cell. When the individual cells are connected in series, the voltage produced by the combination is the algebraic sum of the individual cell voltages. Whereas when the cells are connected in parallel, the resultant current is the algebraic sum of the individual cell currents. So depending upon our power requirement we connect the PV cells in series and parallel combinations to form a Photovoltaic array.

\section{SIMULATION AND RESULTS}
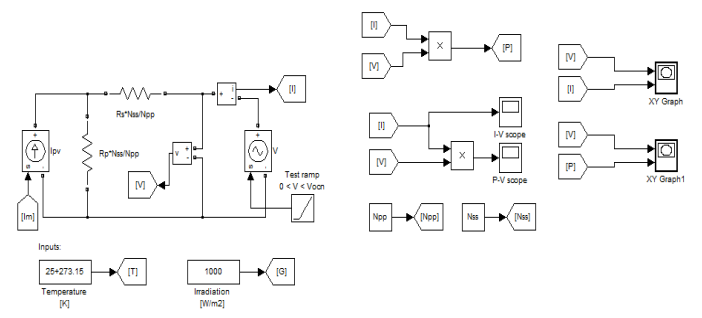

Fig. 5 simulink model of a PV array

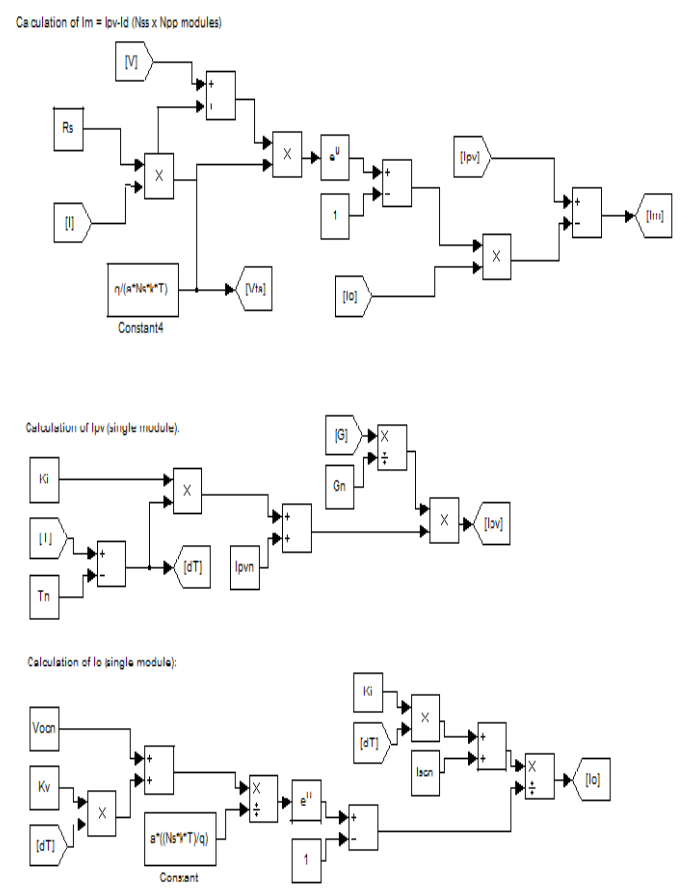

From the Fig it can be observed that, the equations for the photovoltaic current Ipv and diode saturation current Io are modeled individually and then put together to obtain the equation for the PV panel. The series resistance Rs and parallel resistance $\mathrm{Rp}$ for the configuration of our panel is estimated taking into account the number of series and parallel cells (Ns and $\mathrm{Np}$ )

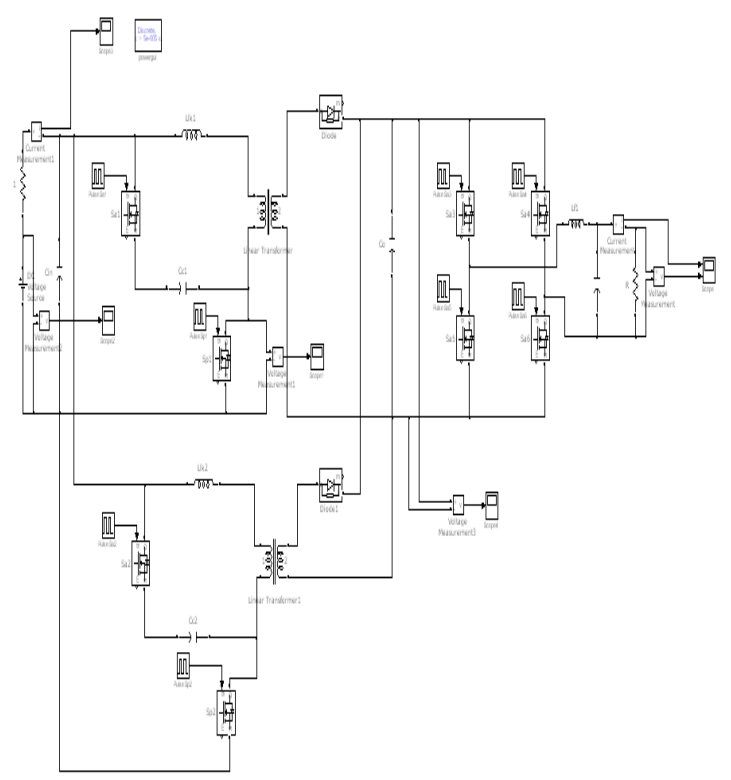

Fig. 7 ILFI simulink model

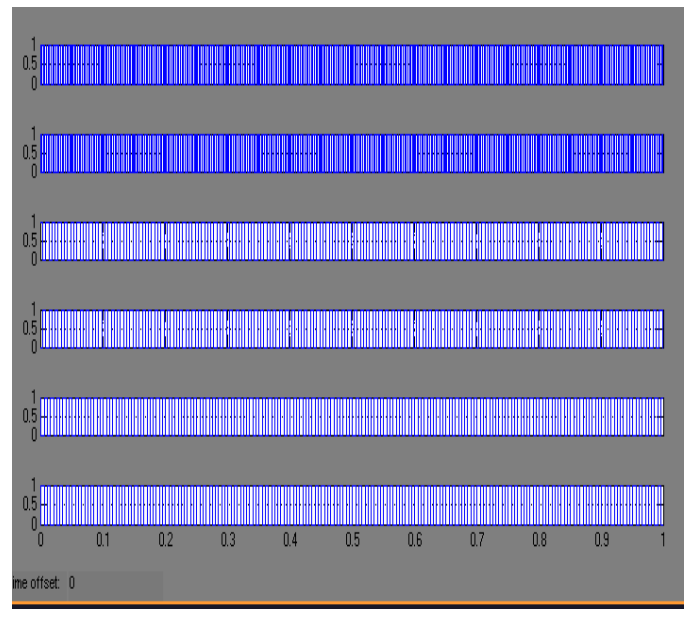

Fig. 8 pulse generation

Fig. 6 subsystem 


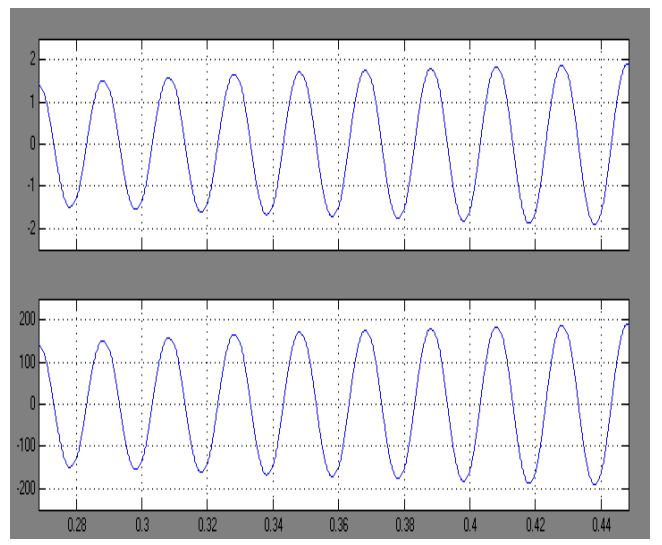

Fig 9 output current and voltage waveform

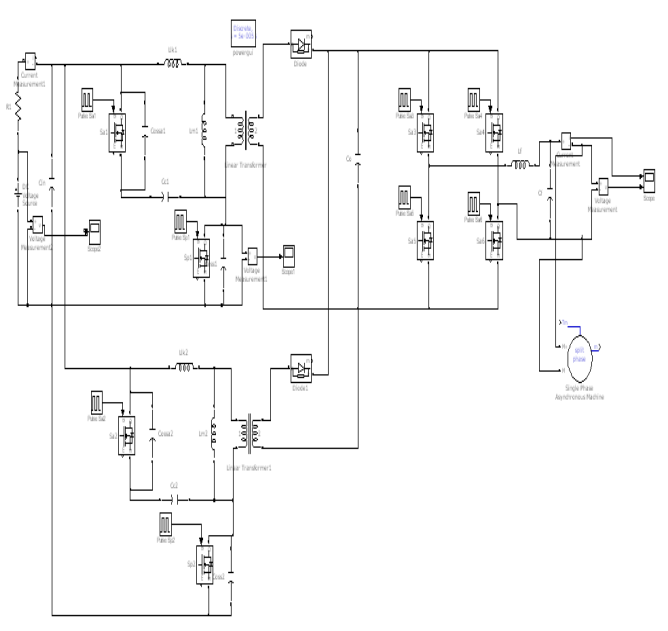

Fig. 10 ILFI fed induction motor model

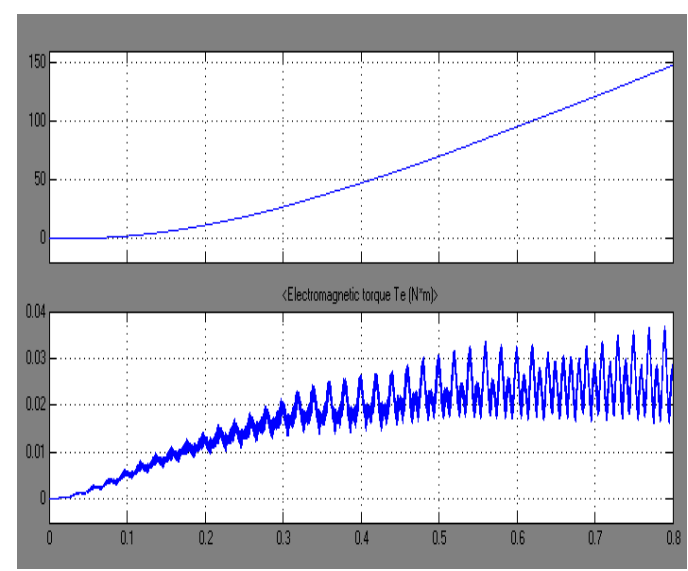

Fig.11 motor speed and torque waveform without PV

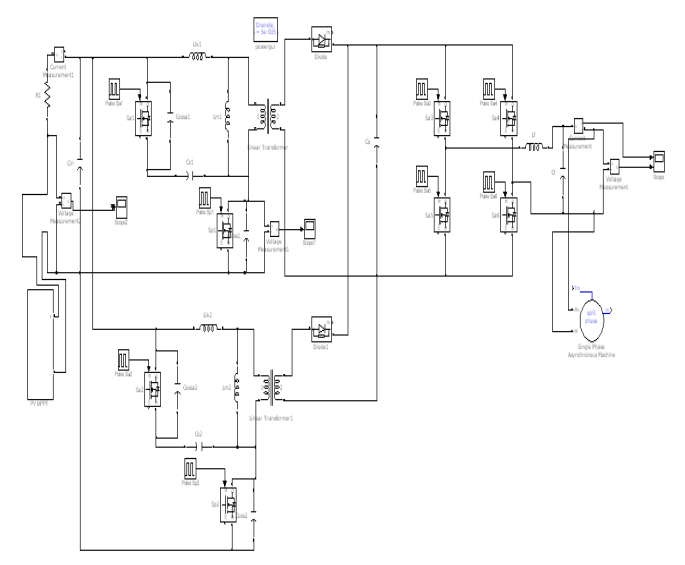

Fig. 12 simulink model with PV

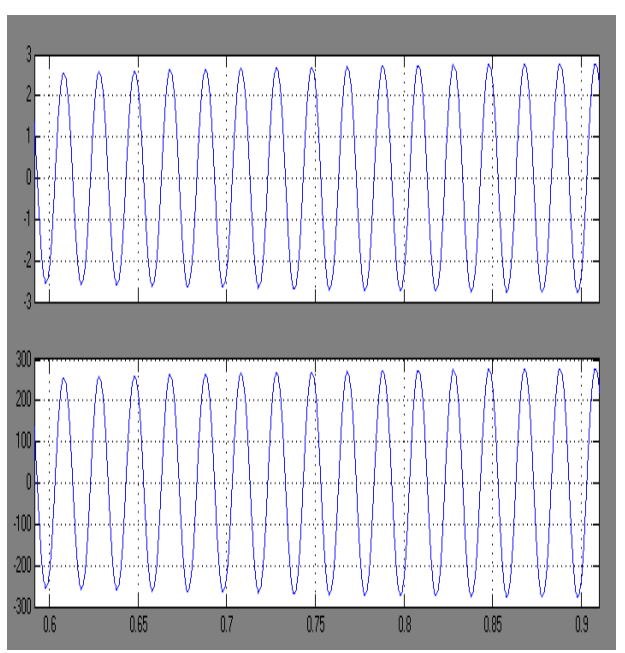

Fig. 13 output current and voltage waveform

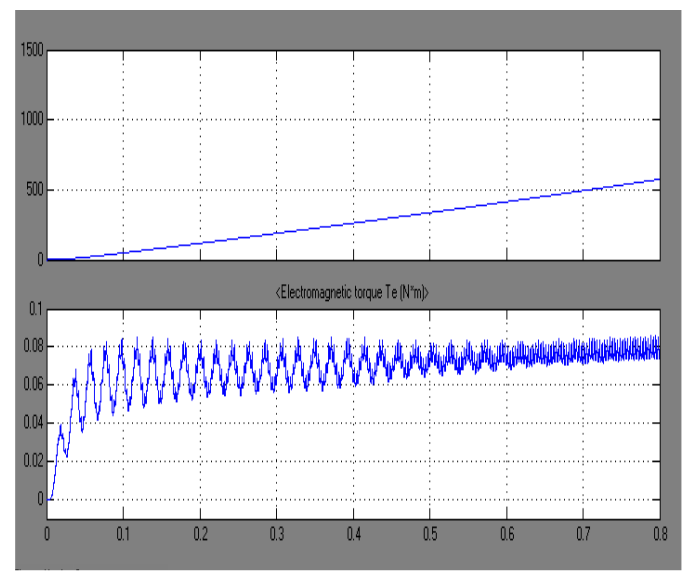

Fig.14 motor speed and torque waveform with PV 
Table 1

\begin{tabular}{|l|l|l|}
\hline Input voltage & Output voltage & Output current \\
\hline $30 \mathrm{v}$ & $140 \mathrm{v}$ & $1.4 \mathrm{~A}$ \\
\hline $50 \mathrm{v}$ & $200 \mathrm{v}$ & $2 \mathrm{~A}$ \\
\hline $75 \mathrm{v}$ & $290 \mathrm{v}$ & $3 \mathrm{~A}$ \\
\hline $100 \mathrm{v}$ & $400 \mathrm{v}$ & $3.9 \mathrm{~A}$ \\
\hline
\end{tabular}

Calculation:

Switching loss: $\quad$ Coss $* \mathrm{Vds} * \mathrm{Fsw}$

$$
=400 * 10^{\wedge}-12 * 70000
$$$$
=0.00154
$$

Motor load: without PV

Input voltage- $100 \mathrm{~V}$

Output current-2A

Output voltage-300V

Motor speed-1300rpm

Motor torque- 0.5

With PV for R load

PV input voltage- $32.4 \mathrm{~V}$

Output voltage- 49V

Output current $-0.3 \mathrm{~A}$

With PV for motor load(single phase induction motor)

PV input voltage-32.4V

Output voltage- $80 \mathrm{~V}$

Output current $-1 \mathrm{~A}$

Motor speed-112rpm

\section{CONCLUSIONS}

Thus the interleaved flyback inverter has been simulated using MATLAB. Active clamp control method has been proposed to reduce the switching loss of the interleaved flyback inverter.the proposed inverter is simulated using PV . this paper can be further improved by using other forms of renewable energy sources.

\section{REFERENCES:}

[1] C. T. Choi, C. K. Li, and S. K. Kok(1999), "Control of an active clamp discontinuousconduction mode flyback converter," in Proc. IEEE Power Electron.Drive Syst. Conf., vol. 2, pp. 1120-1123.

[2] R. Watson, F. C. Lee, and G. Hua (1996), "Utilization of an active-clamp circuitto achieve soft switching in flyback converters," IEEE Trans. PowerElectron., vol. 11 , no. 1, pp. 162-169.
[3] Y.-K. Lo and J.-Y. Lin (2007), “Active-clamping ZVS flyback converter employingtwo transformers," IEEE Trans. Power Electron., vol. 22, no. 6,pp. 2416-2423.

[4] G.-B. Koo and M.-J. Youn (2004), "A new zero voltage switching active clampflyback converter," in Proc. IEEE Power Electron. Spec. Conf., Pp. 508-510.

[5] F. Max Savio, R. Hemantha Kumar and M. Sasikumar (2013), "Power Optimisation and Performance Evolution of High Step-Up Solar PV System For Dc Drives", International Journal of Advanced Research in Electrical, Electronics and Instrumentation Engineering (IJAREEIE), Vol. 2, Issue 10, Pp. 4620-4627.

[6] A.Amalin Rishma and, P.Rajarajeswari (2012), 'High Efficiency Modified Pulse-Width Modulation Bidirectional Converter for Medium Power Drives" International Journal of Application or Innovation in Engineering \& Management (IJAIEM),Vol.1, Issue 2, Pp. 94-100.

[7] T. M. Chen and C.-T. M. Chen and C.-L. Chen (2002), "Analysis and design of asymmetrical halfbridge Flyback converter," IEE Proc.-Electr. Power Appl., vol. 149, no. 6,pp. 433-440.

[8] M.Ragavendran and Dr. M. Sasikumar (2013), "ThreePort Full-Bridge Converters With Wide Voltage Range Input For Solar Power Systems' International Journal Of Engineering And Computer Science, Volume 2 Issue 6,Pp. 1777-1683.

[9] N. Kasa, T. Iida, and L. Chen(2005), "Flyback inverter controlled by sensorless current MPPT for photovoltaic power system," IEEE Trans. Ind. Electron., vol. 52, no. 4, pp. 1145-1152.

[10] D. Fu, Y. Liu, F. C. Lee, and M. Xu (2009), "A novel driving scheme for synchronous rectifiers for LLC resonant converters," IEEE Trans. PowerElectron., vol. 24, no. 9, pp. 1321-1329.

[11] D. Fu, Y. Liu, F. C Lee, andM. Xu(2008), “An improved novel driving scheme ofsynchronous rectifiers for LLC resonant converters," in Proc. IEEE Appl.Power Electron. Conf., pp. 510-516.

[12] A. C. Kyritsis, E. C. Tatakis, and N. P. Papanikolaou (2008), "Optimum design of the current-source flyback inverter for decentralized grid-connected Photovoltaic systems," IEEE Trans. Energy Convers., vol. 23, no. 1, pp. 281-293.

[13] J. Zhang, X. Huang, X. Wu (2010), "A high efficiency Flyback converter with newactive clamp technique," IEEE Trans. Power Electron.,vol. 25, no. 7, p. 17751785.

[14] Sasikumar M. and Chenthur Pandian S. (2012), 'Modified Bi-Directional AC/DC Power Converter with Power Factor Correction', International Journal of Engineering-Transactions B: Applications, Vol. 25, Issue 3, Pp. 175-180. 


\section{REFERENCES}

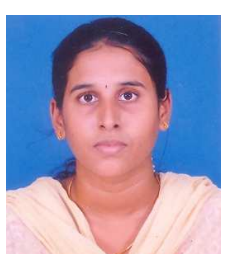

C. Kirthana is currently pursuing the M.E Degree from Jeppiaar Engineering College, Anna University, Chennai, India. He received his B.E degree in Electrical and Electronics Engineering in 2012 from Jeppiaar Engineering College, Anna University, India. His current research interests include Induction Motor Drives and Power Electronics.

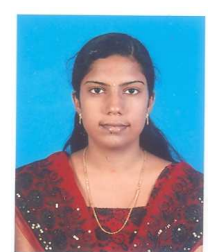

R. Deepa is currently pursuing the M.E Degree from Jeppiaar Engineering College, Anna University, Chennai, India. He received his B.E degree in Electrical and Electronics Engineering in 2012 from Jeppiaar Engineering College, Anna University, India. His current research interests include Induction Motor Drives and Power Electronics.

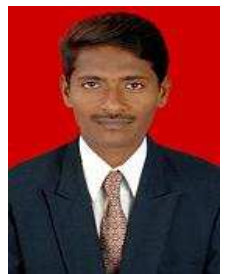

Dr. M. Sasikumar was born in Tamilnadu, India on June 17, 1977. He received the B.E degree in electrical and electronics engineering from K.S.Rangasamy College of Technology, Madras University, India in 1999, and the M.Tech degree in power electronics from VIT University, Vellore in 2006. He has obtained his Ph.d. degree from Sathyabama university, Chennai, tamilnadu, India in 2011. Currently, he is working as a Professor in Jeppiaar Engineering College, Anna University, Chennai. He has 12 years of teaching experience. He has published over 30 technical papers in National and International Conferences /proceedings / journals. 